\title{
The puntOorg International Journal Project
}

\author{
ILARIA BONCORI \\ iboncori@essex.ac.uk \\ University of Essex
}

EDOARDO MOLLONA

edoardo.mollona@unibo.it

University of Bologna

LUIGI MARIA SICCA

luigimaria.sicca@unina.it

University of Naples Federico II

\section{Introduction}

This issue of puntOorg International Journal (PIJ) brings together a number of shared research experiences that began in 2014 when we started the planning of a Special Interest Group (SIG 01) entitled Business for Society, T_01-03 Institutional Resistance, War of Positions and Power Maintenance for the 2015 EURAM $^{1}$ conference in Warsaw. SIG 01 then evolved into a standing track (ST 01_03 Institutional Change, Power, Resistance and Critical Management) for the EURAM 2016 conference in Paris.

Our initial idea was to further 'contaminate' the fields of Organisation Studies and Human Resources Management with political and critical approaches, which have became increasingly popular in various pockets of academic practice over the past two decades but not across all European countries. The Business for Society SIG seemed an ideal avenue to promote this approach and a valuable opportunity to offer continuity of thought and practice to our academic community beyond the individual conference experience. In order to facilitate this approach, we initiated a process called En Attendant EURAM consisting of a series of workshops organised at the Università of Napoli Federico II, the Università of Bologna and the University of Roma Tor Vergata. These workshops allowed participants to kick-start academic conversations and discuss the development of their research projects. Each paper was sent to all participants in the stream mailing list. The author(s) then presented the papers at a workshop in order to foster the creation of a 'discussant community' before the conference itself. The online steaming of our En Attendant EURAM

\footnotetext{
${ }^{1}$ European Academy of Management.
} 
sessions and the video-conference links also allowed us to reach international platforms and colleagues worldwide.

\section{Our approach}

The establishment of Management as an academic discipline has a very brief history when compared with other fields of research both in the humanities sphere and in the realm of scientific studies. Rather than only considering a traditional mainstream approach in terms of organisational studies, we chose to follow a combined approach that also espouses more political and critical understandings.

In a study from 1993, Barbara Czarniawska discussed "organisational labels" understood as instruments of organisational control that have an impact on both desired changes and the management of resistance. As such, organisational labels are seen as artefacts that contribute to the definition of boundaries and thus identities. This approach involves at least two factors that characterise the research work carried out through puntOorg:

- the need to distinguish between types of knowledge - we feel that it is appropriate to take advantage of modern fields of study and scientific domains to make a "paradigmatic shift" à la Khun (1962) from the more traditional type of knowledge;

- the coexistence, on the other hand, of a joining thread between different types of knowledge there is a need not only to espouse the new, but also to recognise the ongoing presence of aggregating elements that bring together different viewpoints and understandings in the intersections between epistemological assumptions, methodological options and subject-specific practice.

The group of scholars and authors in this PIJ issue, coming from different backgrounds, using distinct languages and having various types of knowledge and heterogeneous perspectives, has focussed on the approach, concepts and experiences described above. The need to trace boundaries and identities in the inescapable relationship any researcher has with epistemological assumptions, methodological options and subject-specific practices justified this multifaceted approach. The intellectual exchanges taking place at En Attendant have been carried out on these three levels, as this is where our intimate and sensitive 'research being' lies, regardless of the type of knowledge, language and consensus in our disciplines and communities of practice. Although we all have similar jobs, we are also all different, as we are defined by labels that set boundaries and express identities. This process has been experienced through this issue of PIJ, but also via other research projects within the puntOorg platform aimed at exploring and understanding different ways of being together, without taking for granted or identifying a priori solutions. The objective is the coexistence of and dialogue between different types of knowledge within the sciences and humanities, such as art, philosophy, economics and organisational studies.

The issues discussed below then highlight the importance we place on our method and approach. We pay great attention to the processes (how to do), as much as to the results and performance (what to do/get). This is why it is crucial to highlight how complex the relationship between means and ends always is, within and outside the academic world when dealing with organisational and managerial practices, and when going back to the root of organisational and managerial issues - investigating the underlying assumptions of our 
research practice, questioning ourselves on the epistemological and methodological premises that, consciously or unconsciously, guide our work.

In today's academia, scholars are increasingly required to become more competitive in the commercialisation of their research, in the promotion of their academic profile and in the acquisition of a formal professional status to grant career progression, financial benefits and "survival" in the academic labour market. This climate is spreading through many academic contexts worldwide together with a reduction in public funding and an increase in workloads. In this environment, which may seem at odds with the goals, principles and values of academe, altruistic forms of mentoring and collaboration seem to be increasingly challenging to achieve. Contemporary universities seem to be more and more concerned with customers, products, outcomes, mobility and other terminology borrowed from managerial jargon and theories (see for instance Slaughter and Rhoades, 2004), which we want to believe do not exclude the possibility of the nurturing of ideas, the development of critical approaches and the championing of intellectual freedom. Taking inspiration from Bauman (2006), we wish to challenge the current careful intellectual Daedalus approach by creating and fostering an approach and a method that goes against the 'market current' to make an Icarus leap that is interdisciplinary, polyglot and embracing. Universities and research have become a "Liquid University" (Batko, 2014) engulfed in a mare magnum of rankings, metrics, bureaucracy, promotion and funding opportunities which makes it increasingly withdrawn from the provision of reliable and complete knowledge in its original quest for truth and wisdom.

\section{Praxis in the academic endeavour}

The presentations, thoughts and dialogues that we stimulated in the course of the En Attendant meetings are materialisations of the philosophy of praxis that informs our existence as academicians.

The concept of praxis is rooted in the work of ancient Greek philosophers, who described praxis as the doing, distinguished from the activities of thinking or making (poiesis). According to Aristotle, praxis produced economic and political knowledge. In the Marxian framework, the concept of praxis is fundamental and refers to the idea that human praxis includes not only labor, but also all the activities that materialise into social relationships, institutions and needs. However, it is with the work of Italian Marxist political thinkers, such as Labriola and Gramsci, that the concept of praxis acquired the specific meaning that inspired our work within academia. For example, Gramsci states that a philosophy of praxis calls for the unity between theory and practice. This unity also implies that being cannot be disjointed from thinking, and the subject cannot be separated from the object. In this light, according to the philosophy of praxis, the philosopher (as an individual or a social group) not only captures the contradictions that characterise societies, but also is in him or herself an element of such a contradiction. Therefore, the philosopher leverages the contradiction as both an epistemic principle and a principle for action (Gramsci, 1975: 1487).

However, as Filippini suggests, in Gramsci, the problem that a philosophy of praxis has to deal with is that of the mechanisms that control the transition from a philosophical conception of the world - in our case the academic world - to its praxis (2017: 84-85). Along these lines, we conceived the seminars in the En Attendant format as one of the mechanisms 
functional to a philosophy of praxis. In these seminars, authors not only deliver speeches and present results, but also reflect on being academicians. At least as important as the results of a research project is the act of presenting results. In addition to explaining why specific results add to existing research or (to adapt to the typical parlance that is hegemonic in the management field) fill a specific gap in the literature, researchers are challenged to explain how their research reflects their imagined identity of academicians.

Therefore, in the seminars, we try to reconnect the object of the research process with the process itself; researchers reflect on their roles as researchers. This mechanism, we suggest, facilitates a dialectical interpretation of the identity of academia itself. As Seo and Creed (2002), suggest, "Praxis may be a core concept for reconciling two seemingly incompatible proper- ties of institutional theory: institutional embeddedness and transformational agency" (223). In creating the En Attendant cycle of seminars, we hope to stimulate institutional agency and entrepreneurship in the academic world and to create settings, processes and evaluation criteria able to fully acknowledge the complex nature of the academic profession. In this light, the En Attendant seminars, in connection with the puntOorg platform, try to disembed typical academicians' practices (for example presenting and publishing) from the liturgy and rhetoric accepted in the academic world.

Two aspects that embody our approach are present in this issue of PIJ: the contents of our EURAM track and the puntOorg Working Paper Nursery experience.

\section{Our EURAM track ST_01-03 Institutional Resistance: War of Positions and Power Maintenance.}

This track addresses the paradox of institutional change, the resistance that it faces and the contradictions that it incites or reveals. Given the scope of the issue, we articulated our call for papers in two segments:

- the first specifically addresses issues of institutional change;

- the second tackles the contradictions that institutional change both faces and generates.

\section{Institutional change}

Institutionalist and management theories are more concerned with regularities rather than events, crises involving uncertainty. Paradoxically enough, institutions defined through their persistence seem increasingly to be dominated by multifactorial causes of change. The track explores this apparent paradox and the two sides of organisations understood as persisting institutions and changing social systems.

Our purpose is to understand why institutions and organisations change (or why they do not) despite their inertia and their domination over individual members through routines and regularities. We look for papers that contribute to the advance of institutional theory by coupling persistence and change. How do individual actors or coalitions of actors (traders, entrepreneurs, managers, ordinary employees) and actants (such as Eurozone crises) contribute to institutional dynamics? To what extent are managers effectively monitoring 
institutional change? What is the role of democracy and cooperation to initiate and explain change?

Empirically we welcome papers about non-mimetic behaviours within cultural contexts of order. We also welcome papers that support the domination of rules, norms and mimetic processes to explain change.

Theoretically, this track strives to investigate:

- the components of interpretive contexts dealing with institutional change;

- the role of deliberate and non-deliberate changes in social innovation;

- the conflict between democracy and institutional isomorphism in the making of change.

\section{Power, Resistance and Critical Management}

When addressing institutional change, literature emphasises the role of power. In this perspective, institutional agency is understood as both the power to change institutions and the power to resist change.

The track investigates the connected issues of institutional change, power and resistance. The latter is both interpreted as the institutional work of elites who try to maintain their hegemony and exploitative power and the one enacted by dominated actors who resist and counteract exploitation and the establishing of hegemony.

We invite papers that:

- theoretically engage with the concepts of power, exploitation and resistance;

- empirically analyse how resistance, exploitation and power materialise in organisational life and in institutional fields;

- offer a critical discussion of managerial and economic mainstream analysis and, for this very reason, are themselves an act of resistance to west-centric and colonial rhetoric.

More specifically, we call for papers that investigate:

- a critical approach to management;

- art as a form of resistance;

- resistance in academia;

- power asymmetries in and around organisations;

- dialectical tension between inclusion of, and resistance to, diversity in organisations through an historical approach;

- neo-Gramscian approach in management and organisation studies;

- neo-Marxism and the evolution of forms of exploitation and its impact on life;

- resistance as preservation of vocabularies and categories;

- corporate political action and lobbying influence on institutional change; 
- the issues of control and domination through the comparison with another, alternative critical option oriented towards the model of spontaneous order (SelfOrganisation).

\section{The puntOorg Working Paper Nursery experience}

Our puntOorg Working Paper Nursery stems from the pivotal issues regarding method, approach and content highlighted above. This is a project that involves two substantial differences when compared to our other puntOorg initiatives - the book series and Block - as the Working Paper Nursery only considers work produced in English and does not involve any formal peer review as it is based on mentoring. On the other hand, the book series welcomes research in any language and follows the traditional review process that is common in academic research. Block is a project aimed at artists that stems away from traditional organisational genres of publication (i.e. for instance music, photography, drawings and notes are all included) and is once again open to all languages.

One of the key traits of our Working Paper Nursery is the role of mentors, who nurture the growth of papers/articles/chapters together with our authors instead of offering a blind review as is now customary in most top level international publication outputs. Our puntOorg Working Paper Nursery offers a space and time for acceptance because we believe in supporting each stage of the life cycle in a research project, not only the final product. The Nursery is a place for the growth of qualities and ideas. We counteract the mainstream dichotomy of acceptance versus rejection by establishing a communicative and collaborative bridge between minds, subjects of expertise, generations, networks and organisations.

\section{The papers in this special issue}

The four papers collected in this special issue are aligned with the delineated approach.

Maldonato, in his piece entitled The unconscious logic of decision-making, recalls the genealogy of decision-making processes travelling across differentiated epistemological positions. A path is traced from the colonisation of earth by the human species to the present and explores the relationship between thought and action and means and ends.

Goldoni's work criticises a rhetorically creativity-dominant society with the support of four texts by two authors. The first one by Benjamin, Capitalism as Religion and the other three by Nietzsche, The Joyful Wisdom, Thus Spoke Zarathustra, and The Genealogy of Morals. Through interpretation of these texts, the author analyses merit and creativity as a category of fairness in our society. This opens up discussion and creates awareness of things taken for granted, giving new understanding to capitalism as blackmail and as a mechanism of inequality and exclusion.

Faldetta reflects upon organisational justice drawing on the Levinasian concept. In this sense, justice need not be considered as an individual perception, nor as an institutional agreement. It can be considered as the result of responsibility, that is, from a Levinasian point of view, an a priori category of ethics. The normative use of justice, that often ends up creating injustice, is reconsidered to offer a view that is beyond rationality and is an intuitive concept of 'being there for the other' that is placed before any norms or rules. 
Bizjak's contribution is an exploration of new opportunities for organisational theories, drawing on the concept of performativity framed by Judith Butler in 1990. Through the two categories of identity and gender, well grounded in organisation theory, he tries to catch the opportunity to queer the evolution of these two concepts. In fact, whereas identity is considered as a construction process and gender as the result of prediscursive practices, organisations could grasp new tools to inquire into most of the dichotomies that impact on the daily organisational practices.

The work of Fumagalli is an analysis of the accumulation and valorisation processes at the heart of the capitalist system and highlights the transition towards a new kind of capitalism - bio-cognitive capitalism.

In bio-cognitive capitalism, the processes of accumulation and exploitation focus on learning and relational networks thereby subjugating social phenomena and creating value from the development of forms of social cooperation. Fumagalli refers to the Commonwealth as an expression of social cooperation and of the general intellect and suggests that the appropriation of this Commonwealth is the core of bio-cognitive capitalism. The reference is of course to the forms of property that are secured, for example, the gains from social interaction that accrue to owners of social networks (e.g. Facebook or Google).

In addition, Fumagalli not only describes how new technologies have deeply affected the mechanisms of capitalist accumulation, but also how financialisation has modified the mechanisms of valorisation and its hierarchical structure. The consequence of this line of reasoning leads to the gist of Fumagalli's argument: to be free, the Commonwealth needs to be endowed with financial autonomy. With the possibility to issue its own currency, the Commonwealth can be free to organise itself and to escape from a logic of exchange value production and from budget constraints imposed by austerity policies. This contribution provides an extremely useful lens to interpret key emerging trends of change within a robust theoretical framework.

This is a time in which public opinion struggles between the rhetoric of the fourth industrial revolution brought about by Silicon Valley and the news reporting alleged violations of norms of conduct, such as large internet companies who attempt to escape taxation. This paper helps place the power relations between large internet companies and institutions in a wider perspective.

\section{Keywords}

Power; resistance; hegemony; institutional change; symbolism; agency.

\section{Reference list}

Abell, D.F. (1980) Defining the business: The starting point of strategic planning, Englewood Cliffs: Prentice Hall.

Alvesson, M., Ashcraft, L.K., Alvesson, R.T. (2008) "Identity Matters: Reflections on the construction of identity scholarship in organization studies", Organization, 15 (1): 5-28.

Alvesson, M., Willmott, H. (2002) "Identity regulation as organizational control: Producing the appropriate individual", Journal of Management Studies, 39 (5): 619-644. 
Batko, R. (2014) "Liquid University", In J. Kociatkiewicz and M. Kostera (eds) Liquid Oganization, Abingdon: Routledge: 104-119.

Bauman, Z. (2006) Liquid Fear, Cambridge: Polity Press.

Bizjak, D., Calcagno, M., Sicca, L.M. (2017) “Going Back to the Roots of Entrepreneurship: Empirical Evidences from the Practice of Dance", Academia Revista Latinoamericana de Administración, 30 (2): 173-191.

Bloor, D. (1976) Knowledge and Social Imagery, Illinois, Chicago: The University of Chicago Press.

Bohm, S., Spicer, A., Fleming, P. (2008) "Infra-political dimensions of resistance to international business: A neo-Gramscian approach", Scandinavian Management Journal, 24 (3): 169-182.

Bourdieu, P. (1977) Outline of a Theory of Practice, Cambridge, UK: Cambridge University Press.

Bourdieu, P. (1986) "The forms of capital", In J.C. Richardson (ed), Handbook of theory and research for the sociology of education, Westport, CN: Greenwood Press.

Bourdieu, P. (1990), The logic of practice, Cambridge, MA: Harvard University Press.

Bourdieu, P. (1991) Language and symbolic power, Cambridge, MA: Harvard University Press.

Bourdieu, P. (2005) “The Political Field, The social Science Field and the Journalistic Field", In R. Benson and E. Neveu (eds), Bourdieu and the journalistic field, pp. 29-47, Cambridge, UK: Polity Press.

Czarniawska-Joerges, B. (1993) The Three-dimensional Organization: A Constructionist View, Lund: Studentlitteratur.

Deleuze, G. (1990) "Post-scriptum sur le societies de contrôle", In G. Deleuze, Pourparlers 1972-1990, Paris: Editions de Minuit.

Fayard, A.L., Weeks, J. (2011) “Who Moved my Cube”, Harvard Business Review, 89 (7/8): 1-8.

Feyerabend, P.K. (1981) Science as Art (Philosophical Papers, Vol. 2), Cambridge: Cambridge University Press.

Filippini, M. (2017) Using Gramsci. A new approach. London, UK: Pluto Press.

Fleming, P. (2006) "Sexuality, Power and Resistance in the Workplace", Organizational Studies, 28 (2): 239-256.

Fleming, P., A. Spicer (2014), "Power in Management and Organization Science", The Academy of Management Annals, 8 (1): 237-298.

Fumagalli, A. (2007) Bioeconomia e capitalismo cognitivo. Verso un nuovo paradigma di accumulazione, Roma: Carocci Editore.

Gombrich, E.H. (1959) Art and Illusion. A Study in the Psychology of Pictorial Representation, Washington, DC: Trustees of The National Gallery of Art.

Gombrich, E.H., Hochberg, J., Black, M. (1978) Art, Perception, and Reality, Baltimore/London: Jonhs Hopkins University Press.

Goodman, N. (1978) Ways of Worldmaking, New York, NY: Hackett. 
Gramsci, A. (1971) "Selections from the prison notebooks" New York: international Publishers.

Gramsci, A. (1975) Quaderni dal Carcere, Torino, Italy: Giulio Einaudi Editore.

Hax, A.C., Majluf, N., (1984) Strategy Concept and Process: A Pragmatic Approach (italian edition: (1991), La gestione strategica dell'impresa (a cura di L.M. Sicca), Napoli, Edizioni Scientifiche Italiane).

Lakatos, I. (1978) The Methodology of Scientific Research Programmes (Philosophical Papers, Vol. 1), Cambridge: Cambridge University Press.

Kuhn, T. (1962), The Structure of Scientific Revolution, Chicago: University of Chicago Press.

Latour, B., Woolgar, S. (1979) Laboratory Life: The Construction of Scientific Facts, Princeton: Princeton University Press.

Lawrence, T.B., Mauws, M.K., Dyck, B., and R. F. Kleysen. (2005) “The Politics of Organizational Learning: Integrating Power into the 4I Framework, Academy of Management review, 30 (1): 180-191.

Lawrence, T.B. (2008) "Power, Institutions and Organizations", In R. Greenwood, C. Oliver, K. Sahlin, and R. Suddaby (Eds), The SAGE handbook of Organizational Institutionalism, pp. 170-197, London: Sage.

Lawrence, T.B., Malhotra, N., T. Morris (2012), "Episodic and Systemic Power in the Transformation of Professional Service Firms", Journal of Management Studies, 49 (1): 102143.

Levy, D., M. Scully (2007) “The Institutional Entrepreneur as Modern Prince: The Strategic Face of Power in Contested Fields", Organization Studies, 28 (7): 971-991.

Martí, I., P. Fernández (2013) "The Institutional Work of Oppression and Resistance: Learning from the Holocaust", Organization Studies, 34 (8): 1195-1223.

Mintzberg, H. (1973) "Strategy Making in Three Modes", California Management Review, 16 (2): 44-53.

Mintzberg, H. (1976) "Planning on the Left Side and Managing on the Right", Harvard Business Review, July 1976: 49-58.

Oliverio, S. (2012), "The Most Beautiful Harmony and Education as a Moral Equivalent of War: A Deweyan-Heraclitean Perspective", Civitas Educationis. Education, Politics and Culture, 1 (1): 113-132.

Pandolfi, M., L. McFalls (2010) “Global Bureaucracy. Indifferent bur not Irresponsible”, In A. Da Lago and Palidda S., Conflict, Security and the Reshaping of Society. The Civilization of War, pp. 171-184, Routledge: UK.

Pfeffer, J. (1981) “Management as Symbolic Action: The Creation and Maintenance of Organizational Paradigms", In L.L. Cummings, B.M. Staw (eds), Research in organizational behavior (Vol. 3), pp. 1-52, Greenwich, CT: JAI Press.

Popper, K.R. (1934) The logic of Scientific Discovery, ${ }^{\circ}$ Karl Popper.

Popper, K.R. (1956) Postscript to the Logic of Scientific Discovery: Realism and Aim of Science, Karl Popper. 
Porter, M.E. (1985) "Competitive advantage: Creating and sustaining superior performance", New York, NY.

Seo, M.G., Creed, W.E.D. (2002) "Institutional Contradictions, Praxis, and Institutional Change: A Dialectical Perspective". The Academy of Management Review, 27 (2): 222247.

Sicca, L.M. 2000 “Chamber Music and Organization Theory. Some Typical Organizational Phenomena seen Under the Microscope", Culture and Organization, 6 (2): 145-168.

Sicca, L.M., L. Zan (2005) "Much ado About Management. Managerial Rhetoric in the Trasformation of Italian Opera Houses", International Journal of Arts Management, Spring (3): 46-64.

Sicca, L.M. (2005) "Organizing Chamber Music as Culture", Aam Tac, Arts and Artifacts in Movie: Technology, Aesthetics, Communication, 2 (2): 129-142.

Sicca, L.M., Zan, L. (eds) (2014) Management Arti Culture. Resoconto del primo anno di attività del GSA - Accademia Italiana di Economia Aziendale, Napoli: Editoriale Scientifica.

Simon, H. (1947) Administrative Behavior: A Study of Decision-Making Processes in Administrative Organization, New York: Macmillan.

Slaughter, S., Rhoades, G. (2004) Academic Capitalism and the New Economy: Markets, State, and Higher Education, Baltimore: Johns Hopkins University Press.

Strati, A. (1999) Organization and aesthetics, London: Sage.

Strati, A. (2000) Theory and Method in Organization Studies Paradigms and Choices, London: Sage.

Walras, L. (1874) Elements d'economie politique pure, Lausanne, Switzerland: Corbas.

Wenger, E. (1998) Communication of Practice: Learning, Meaning and Identity, New York: Cambridge University Press. 